\title{
HUBUNGAN ANTARA WHR DENGAN KADAR Hs-CRP SERUM PADA MAHASISWA OBES DAN TIDAK OBES DI FAKULTAS KEDOKTERAN UNIVERSITAS SAM RATULANGI MANADO
}

\author{
${ }^{1}$ Ezra Toreh \\ ${ }^{2}$ Shirley E. S. Kawengian \\ ${ }^{2}$ Alexander S. L. Bolang \\ ${ }^{1}$ Kandidat SkripsiFakultasKedokteranUniversitas Sam Ratulangi Manado \\ ${ }^{2}$ BagianIlmuGiziFakultasKedokteranUniversitas Sam Ratulangi Manado \\ Email: ezratoreh@yahoo.com
}

\begin{abstract}
Central obesity is recognized as a major factor that associated with increased risk for some chronic diseases. Waist to hip ratio described the increase in visceral adipose tissue and subcutaneous fat on waist circumference and hip circumference.C-reactive protein is the detection of cardiovascular disease risk in conventional but not sensitive enough to detect cardiovascular risk so beused the new method is of high sensitivity C-reactive protein.The research have purpose to know the difference and relationship of waist to hip ratio and high sensitivity c-reactive protein level between obese and non-obese students at Medical Faculty of Sam Ratulangi University Manado.This research was an observational analytic crosssectional approach. The results of statistical analysis using the Mann-Whitney $\mathrm{U}$ test revealed that there were significant differences $(p=0.000<0.05)$ both WHR and hs-CRP level in both groups of students are.Conclusion:The results of statistical analysis using the Spearman test showed that there is a positive very weak relationship $(\mathrm{r}=0309)$ and significant $(\mathrm{p}=0017$ $<0.05$ ) between the values of WHR with hs-CRP level in obese and non-obese students at Medical Faculty of Sam Ratulangi University Manado.
\end{abstract}

Keywords: WHR, hs-CRP.

\begin{abstract}
Abstrak: Obesitas sentral diakui sebagai faktor utama yang dikaitkan dengan peningkatan resiko untuk beberapa penyakit kronis. Waist to hip ratio (WHR) menggambarkan peningkatan jaringan adiposa visceral dan lemak subkutan pada lingkar pinggang dan lingkar pinggul. C-reactive protein (CRP) merupakan deteksi risiko penyakit kardiovaskular tapi secara konvensional tidak cukup sensitif untuk mendeteksi risiko kardiovaskular sehingga digunakan metode baru yaitu high sensitivity C-reactive protein (hsCRP). Penelitian bertujuan untuk mengetahui perbedaan dan hubungan waist to hip ratio (WHR) dengan kadar high sensitivity c-reactive protein (hs-CRP) serum pada mahasiswa obes dan tidak obes di Fakultas Kedokteran Universitas Sam Ratulangi Manado. Penelitian ini bersifat observasional analitik dengan menggunakan pendekatan cross-sectional. Hasil analisis statistik dengan menggunakan uji Mann-Whitney $U$ menunjukan terdapat perbedaan yang bermakna $(\mathrm{p}=0.000<0.05)$ baik WHR maupun kadar hs-CRP serum pada kedua kelompok mahasiswa tersebut. Simpulan: Hasil analisis statistik dengan mengguna-kan uji Spearman menunjukan bahwa terdapat hubungan yang positif sangat lemah $(\mathrm{r}=0.309)$ dan bermakna $(\mathrm{p}=0.017<0.05)$ antara nilai WHR dengan kadarhs-CRP serum mahasiswa obes dan tidak obes pada Fakultas Kedokteran Universitas Sam Ratulangi Manado.
\end{abstract}

Kata kunci: WHR, hs-CRP. 
Sindroma metabolik merupakan suatu kumpulan kelainan metabolik baik lipid maupun tidak lipid yang merupakan faktor risiko penyakit kardiovaskuler, yang salah satunya adalah obesitas sentral. ${ }^{\mathbf{1}}$ Obesitas merupakan kondisi abnormal atau kelebihan lemak yang serius dalam jaringan adiposa sehingga mengganggu kesehatan. Obesitas saat ini telah menjadi ancaman kesehatan di seluruh dunia. ${ }^{2}$ Data Statistic International Obesity Task Force melaporkan lebih dari 30\% populasi di Eropa Timur menderita obesi-tas. Berdasarkan data The National Health and Nutrition Examination Survey (NHANES), selama periode 2007-2008 diketahui prevalensi obesitas pada orang dewasa di Amerika sebesar 33,8\%. Prevalensi obesitas pada laki-laki sekitar $32,2 \%$ dan pada perempuan sebesar $35,5 \% .{ }^{3}$ Data Riskesdas 2007, prevalensi nasionalobesitas umum di Indonesia pada penduduk umur 15 tahun atau lebih adalah 10,3\%.Berdasarkan jenis kelamin pada laki-laki umur 15 tahunatau lebih adalah $13,9 \%$, sedangkan perempuan Umur 15 tahun atau lebih adalah 23,8\%. Prevalensi nasional Obesitas Sentral di Indonesia pada penduduk umur 15 tahun atau lebih adalah $18,8 \% .{ }^{4}$ Banyak cara yang dipakai untuk menentukan obesitas seperti Indeks Massa Tubuh (IMT), Standar Broca, penentuan total lemak tubuh dengan pengukuran tebal lemak bawah kulit atau melalui distribusi penyimpanan lemak dalam tubuh dan pemeriksaan lainnya yang bersifat invasif. Berdasarkan distribusi lemak tubuh dapat dilakukan pengukuran waist circumferrence (WC) dan WHR. Pengukuran ini mudah, cepat, tidak invasif, dan hanya menggunakan alat ukur meteran yang terbuat dari plastik dan dapat menggambarkan status gizi seseorang saat itu. ${ }^{5}$ Obesitas sentral sendiri telah diakui sebagai faktor utama yang dikaitkan dengan peningkatan risiko untuk beberapa penyakit kronis. Penilaian WHR menggambarkan peningkatan jaringan adiposa viseral dan lemak subkutan pada lingkar pinggang serta penurunan otot gluteofemoral pada lingkar pinggul. Hal ini merupakan pengaruh yang telah diakui sebagai kunci untuk memahami hubungan WHR terhadap risiko penyakit kronis. ${ }^{6}$ Hasil penelitian juga membuktikan bahwa terdapat hubungan erat antara obesitas dan faktor risiko penyakit kardiovaskular seperti diabetes mellitus tipe II, dislipidemia dan hipertensi. Bertambahnya populasi obesitas dengan sendirinya akan meningkatkan angka kesakitan dan kematian penyakit kardiovaskuler. Laporan World Health Organisation (WHO) tahun 2003, kematian akibat penyakit kardiovaskuler mencapai $29,2 \%$ dari seluruh kematian di dunia atau 16,7 juta jiwa setiap tahun. Dari jumlah kematian tersebut, 80\% diantaranya terdapat di negara miskin, menengah dan negara berkembang. ${ }^{7} C$ reactiveprotein (CRP) sendiri sekarang telah digunakan untuk mendeteksi risiko penyakit kardiovaskular yang dapat dilakukan dengan mengukur protein yang disintesis di hati sebagai respon terhadap berbagai rangsang inflamasi. Karena sekarang diketahui pemeriksaan CRP dengan metode konvensional tidak cukup sensitif untuk mendeteksi risiko kardiovaskular sehingga digunakan metode baru yaitu high sensitivity C-reactive protein (hsCRP). Penelitian epidemiologis melaporkan bahwa risiko penyakit kardiovaskuler digolongkan kedalam rendah, sedang dan tinggi jika kadar high sensitivity C-reactive protein (hsCRP) masing masing kurang dari $1 \mathrm{mg} / \mathrm{L}, 1-3 \mathrm{mg} / \mathrm{L}$, dan lebih dari 3 mg/L. ${ }^{8}$ Berdasarkan uraian latar belakang yang sudah disampaikan diatas, maka peneliti tertarik untuk mengadakan penelitian pada mahasiswa di Fakultas Kedokteran Universitas Sam Ratulangi Manado bagaimana hubungan WHR untuk menentukan status obesitas dengan kadar hs-CRP.

Penelitian ini bertujuan untuk mengetahui perbedaanWHR pada mahasiswa obes dan tidak obes di Fakultas Kedokteran Universitas Sam Ratulangi Manado, mengetahui perbedaan kadar hs-CRP serum pada mahasiswa obes dan tidak obes di Fakultas Kedokteran Universitas Sam Ratulangi Manado, dan mengetahui hubungan antara WHR dan kadar hs-CRP serum pada mahasiswa obes dengan tidak obes di Fakultas Kedokteran Universitas 
Sam Ratulangi Manado.

\section{METODE}

Penelitian ini merupakan penelitian observasional analitik dengan pendekatan cross sectional, berlangsung pada bulan November 2012-Januari 2013 di Fakultas Kedokteran Universitas Sam Ratulangi Manado, Sulawesi Utara.

Populasi adalah Seluruh mahasiswamahasiswi Fakultas Kedokteran Universitas Sam Ratulangi Manado. Sampel berjumlah 59 diambil dari populasi dengan menggunakan kriteria responden yaitu bersedia menjadi sampel dengan menanda tangani informed consent dan berusia 18 tahunatau lebih tapi tidak sedang sakit dan dalam program diet. Responden awalnya ditetapkan dalam dua kelompok yaitu mahasiswa obes yaitu mahasiswa yang memenuhi kriteria obes menurut IMT berdasarkan kriteria Asia Pasifik yaitu obes 25atau lebih, dalam satuan $\mathrm{kg} / \mathrm{m}^{2}$. Mahasiswa tidak obes yaitu mahasiswa yang memenuhi kriteria normal menurut IMT berdasarkan kriteria Asia Pasifik yaitu normal 18,5-22,9, dalam satuan $\mathrm{kg} / \mathrm{m}^{2}$. IMT responden didapat dengan mengukur tinggi badan dan berat badan responden. Tinggi badan responden di-ukur dengan menggunakan microtoise merek general care dengan tingkat ketelitian $0,1 \mathrm{~cm}$ dan berat badan responden diukur dengan menggunakan timbangan merek camry dengan tinkat ketelitian $0,1 \mathrm{~kg}$. Setelah didapatkan nilai IMT maka responden dikelompokan dalam kelompok obes dan tidak obes kemudian responden akan diukur waist to hip ratio dengan pita pengukur merk butterfly brand dengan hasil dalam satuan dan pemeriksaan hs-CRP dengan melakukan pengambilan darah vena 3-5 ml kemudian diukur dengan metode Latex Turbidimetry Immunoassay (LTIA) dengan hasil dalam satuan mg/L.

\section{HASIL}

Jumlah sampel dalam penilitian ini yaitu sebanyak 59 responden yakni kelom- pok jenis kelamin terdapat 30 laki-laki (50\%) dan 29 perempuan (49,2\%). Untuk umur yang terbanyak yaitu umur 21 tahun $(32,2 \%)$ sedangkan untuk umur yang jumlahnya paling sedikit adalah umur 22 tahun dengan presentase 6,8\%. Adapun tempat tinggal responden sebagian besar bertempat tinggal di Kost dengan presentase $57,6 \%$. Adapun pekerjaan orang tua terbanyak adalah PNS dengan presentase $57,6 \%$ dan presentase paling sedikit untuk pekerjaan orang tua adalah petani dengan nilai 3,4\% (Tabel 1).

Diperoleh nilai WHR rata-rata responden yakni $0,81 \pm 0,70$ dengan nilai minimum sebesar 0,67 dan nilai maksimum sebesar 0,97. Pada kelompok tidak obes, didapatkan rata-rata nilai WHR responden yakni $0,77 \pm 0,04$ dengan nilai minimum sebesar 0,67 dan nilai maksimum sebesar 0,86. sedangkan pada kelompok obes, didapatkan rata-rata nilai WHR responden yakni 0,85 $\pm 0,06$ dengan nilai minimum sebesar 0,72 dan nilai maksimum sebesar 0,97 (Tabel 2).

WHR tidak beresiko yaitu sebanyak 46 responden (78\%), sedangkan responden dengan WHR beresiko yaitu sebanyak 13 responden (13\%). Pada kelompok tidak obes, responden dengan WHR tidak beresiko yaitu sebanyak 28 responden $(96,6 \%)$ dan dengan WHR beresiko yaitu sebanyak satu responden (3,4\%). Sedangkan pada kelompok obes, responden dengan WHR tidak beresiko yaitu sebanyak 18 responden (60\%) dan dengan WHR beresiko yaitu sebanyak 12 responden (40\%) (Tabel 3).

Didapatkan rata-rata nilai hs-CRP responden yakni $1,32 \pm 0,87$ dengan nilai minimum sebesar 0,1 dan nilai maksimum sebesar 9,5. Pada kelompok tidak obes, didapatkan rata-rata nilai hs-CRP responden yakni 0,62 $\pm 0,70$ dengan nilai minimum sebesar 0,1 dan nilai maksimum sebesar 2,6. Sedangkan pada kelompok obes, didapatkan rata-rata nilai hs-CRP responden yakni 2,01 $\pm 2,36$ dengan nilai minimum sebesar 0,2 dan nilai maksimum sebesar 9,5 (Tabel 4).

Responden yang memiliki kadar hsCRP dengan resiko rendah yaitu sebanyak 
37 responden (62,7\%), responden yang memiliki kadar hs-CRP dengan resiko sedang yaitu sebanyak 14 responden $(23,7 \%)$ dan responden yang memiliki kadar hs-CRP dengan resiko berat yaitu sebanyak delapan responden (13,6\%). Pada kelompok tidak obes, respondenyang memiliki kadar hs-CRP dengan resiko rendah yaitu sebanyak21 responden(96,6\%) dan responden yang memiliki kadar hsCRP dengan resiko sedang yaitu sebanyak delapan responden $(3,4 \%)$. Sedangkan pada kelompok obes, responden yang memiliki kadar hs-CRP dengan resiko rendah yaitu sebanyak16 responden (53,3\%), responden yang memiliki kadar hs-CRP dengan resiko sedang yaitu sebanyak enam responden (20\%) dan responden yang memiliki kadar hs-CRP dengan resiko berat yaitu sebanyak delapan responden (26,7\%). (Tabel 5)

Untuk membuktikan hipotesis tentang adanya perbedaan WHR dan hs CRP pada kelompok obes dan tidak obes dengan menggunakan uji non parametric yaitu uji mann-whitney $u$ yang hasil uji statistik diperoleh $p$ untuk aktivitas fisik (nilai MET) yaitu 0,000 yang lebih kecil dari $\alpha$ 0,05 . Sedangkan $p$ untuk hs CRP yaitu 0,000 yang lebih kecildari $\alpha 0,05$. Nilai koefisien (Z) WHRsebesar -4,025 dan nilai koefisien (Z) hs-CRP sebesar -3,552. Hasil uji ini menunjukkan bahwa ada perbedaan WHR dan hs-CRP pada kelompok obes dan tidak obes (Tabel 6).

Untuk membuktikan hipotesis tentang hubungan WHR dengan kadar hs CRP dengan menggunakan uji non parametrik yaitu uji spearman rank yang hasil uji statistik diperoleh nilai koefisien korelasi (r) sebesar 0,306 dan nilai $p$ yaitu 0,017 yang lebih kecil dari $\alpha 0,05$. Hasil uji ini menunjukkan bahwa antara WHR kadar hsCRP memiliki hubungan yang bermakna (Tabel 7).

Tabel 1. Karakteristik Responden.

\begin{tabular}{|c|c|c|c|c|c|c|c|}
\hline \multirow{2}{*}{\multicolumn{2}{|c|}{ KarakteristikResponden }} & \multicolumn{2}{|c|}{ Semua Responden } & \multicolumn{2}{|c|}{ Tidak Obes } & \multicolumn{2}{|c|}{ Obes } \\
\hline & & n & $\%$ & $\mathbf{n}$ & $\%$ & $\mathbf{n}$ & $\%$ \\
\hline \multirow[t]{2}{*}{ JenisKelamin } & Laki-Laki & 30 & 50,8 & 15 & 51,7 & 15 & 50 \\
\hline & Perempuan & 29 & 49,2 & 14 & 48,3 & 15 & 50 \\
\hline \multirow[t]{5}{*}{ Umur } & 18 & 10 & 16,9 & 6 & 20,7 & 4 & 13,3 \\
\hline & 19 & 13 & 22 & 5 & 17,2 & 8 & 26,7 \\
\hline & 20 & 13 & 22 & 6 & 20,7 & 7 & 23,3 \\
\hline & 21 & 19 & 32,2 & 11 & 37,9 & 8 & 26,7 \\
\hline & 22 & 4 & 6,8 & 1 & 3,4 & 3 & 10,0 \\
\hline \multirow[t]{2}{*}{ TempatTinggal } & Orang Tua & 25 & 42,4 & 9 & 31,0 & 16 & 53,3 \\
\hline & Kost & 34 & 57,6 & 20 & 69,0 & 14 & 46,7 \\
\hline Pekerjaan & PNS & 34 & 57,6 & 17 & 58,6 & 17 & 56,7 \\
\hline \multirow[t]{4}{*}{ Orang tua } & Polisi/ABRI & 5 & 8,5 & 1 & 3,4 & 4 & 13,3 \\
\hline & PegawaiSwasta & 2 & 3,4 & 1 & 3,4 & 1 & 3,3 \\
\hline & Wiraswasta & 16 & 27,1 & 9 & 31,0 & 7 & 23,3 \\
\hline & Petani & 2 & 3,4 & 1 & 3,4 & 1 & 3,3 \\
\hline \multirow[t]{2}{*}{ Status Gizi } & Tidak Obes & 29 & 49,2 & & & & \\
\hline & Obes & .30 & 50,8 & & & & \\
\hline
\end{tabular}

Tabel 2. Gambaran nilai Waist to Hip Ratio (WHR) pada responden.

\begin{tabular}{cccc}
\hline & \multicolumn{2}{c}{ WHR (cm) } \\
\hline & Semua Respoden & Tidak Obes & Obes \\
\hline Rata-rata & 0,81 & 0,77 & 0,85 \\
Std. Deviasi & 0,70 & 0,04 & 0,06 \\
Min & 0,67 & 0,67 & 0,72 \\
Max & 0,97 & 0,86 & 0,97 \\
\hline
\end{tabular}


242 Jurnal e-Biomedik (eBM), Volume 1, Nomor 1, Maret 2013, hlm. 238-245

Tabel 3. Gambaran Waist to Hip Ratio (WHR) pada responden.

\begin{tabular}{ccccccc}
\hline & \multicolumn{2}{c}{ Semua Responden } & \multicolumn{2}{c}{ Tidak Obes } & \multicolumn{2}{c}{ Obes } \\
\cline { 2 - 7 } & $\mathbf{n}$ & $\mathbf{\%}$ & $\mathbf{n}$ & $\mathbf{\%}$ & $\mathbf{n}$ & $\mathbf{\%}$ \\
\hline Tidak Beresiko & 46 & 78 & 28 & 96,6 & 18 & 60 \\
Beresiko & 13 & 22 & 1 & 3,4 & 12 & 40 \\
\hline
\end{tabular}

Tabel 4. Gambaran kadar High Sensitivity C Reactive Protein Serum (hs-CRP) pada responden.

\begin{tabular}{cccc}
\hline & \multicolumn{3}{c}{ Hs-CRP (mg/L) } \\
\hline & Semua Responden & Tidak Obes & Obes \\
\hline Rata-rata & 1,32 & 0,62 & 2,01 \\
Std. Deviasi & 0,87 & 0,70 & 2,36 \\
Min & 0,1 & 0,1 & 0,2 \\
Max & 9,5 & 2,6 & 9,5 \\
\hline
\end{tabular}

Tabel 5. Gambaran High Sensitivity C-Reactive Protein (hs-CRP) pada responden.

\begin{tabular}{ccccccc}
\hline & \multicolumn{2}{c}{ Semua Responden } & \multicolumn{2}{c}{ Tidak Obes } & \multicolumn{2}{c}{ Obes } \\
\cline { 2 - 7 } & $\mathbf{n}$ & $\mathbf{\%}$ & $\mathbf{n}$ & $\mathbf{\%}$ & $\mathbf{n}$ & $\mathbf{\%}$ \\
\hline Ringan & 37 & 62,7 & 21 & 96,6 & 16 & 53,3 \\
Sedang & 14 & 23,7 & 8 & 3,4 & 6 & 20 \\
Berat & 8 & 13,6 & 0 & 0 & 8 & 26,7 \\
\hline
\end{tabular}

Tabel 6. Perbedaan WHR dengan kadar hs-CRP pada responden.

\begin{tabular}{cccccc}
\hline $\begin{array}{c}\text { Variabel } \\
\text { Penelitian }\end{array}$ & Status gizi & $\boldsymbol{N}$ & Mean Rank & $\boldsymbol{Z}$ & $\boldsymbol{p}$ \\
\hline Hs-CRP & Tidak Obes & 29 & 21,95 & $-3,552$ & 0,000 \\
& Obes & 30 & 37,78 & & \\
WHR & Tidak Obes & 29 & 20,86 & $-4,025$ & 0,000 \\
& Obes & 30 & 38,83 & \\
\hline
\end{tabular}

Tabel 7. Hubungan nilai WHR dengan nilai hs-CRP.

\begin{tabular}{ccc}
\hline Variabel Penelitian & $\boldsymbol{r}$ & $\boldsymbol{P}$ \\
\hline WHR & 0,309 & 0,017 \\
Hs-CRP & & \\
\hline
\end{tabular}

\section{BAHASAN}

Waist-Hip Ratio atau Waist to Hip ratio merupakan cara penghitungan lain untuk menentukan apakah seseorang sudah mulai menderita obesitas. $^{9}$ Ratio ini merupakan metode yang dapat menilai distribusi jaringan lemak tubuh. Laki-laki memilik ratio yang lebih tinggi dibandingkan perempuan. Ini akibat distribusi lemak laki-laki lebih banyak dibagian pinggang sedangkan perempuan lebih banyak dibagian bokong. Penyebabnya adalah pengaruh efek hormonal selama pubertas. Estrogen yang tinggi pada perempuan mendorong deposisi lemak sekitar bokong lebih banyak (gynoid fat distribution), sedangkan testosterone yang tinggi menyebabkan deposisi lemak sekitar pinggang (android fat distribution). Lakilaki dengan WHR lebih besar dari 1,0 dan pada perempuan lebih besar dari 0,8 
meningkatkan kemungkinan resiko terkena penyakit kardiovaskuler atau diabetes. ${ }^{9}$ pengukuran WHR harus dilakukan oleh tenaga yang terlatih dan posisi pengukuran harus tepat. Perbedaan posisi pengukuran akan memberikan hasil yang berbeda. Tetapi ukuran ketetapan penilai WHR yang dipakai yaitu mengikuti standar WHO yaitu untuk pria lebih dari $0.90 \mathrm{~cm}$ dan wanita lebih dari $0.85 \mathrm{~cm}$ sudah memiliki resiko meningkat terhadap penyakit. ${ }^{10}$

Hasil penelitian yang didapat, nilai WHR terendah dari responden yaitu 0,67 dan tertinggi nilainya adalah 0,97 dengan rata-rata nilai 0,81. Pada kelompok responden tidak obes nilai WHR terendah dari responden yaitu 0,67 dan tertinggi nilainya adalah 0,86 dengan rata-rata nilai 0,77 . Sedangkan pada kelompok responden obes nilai WHR terendah dari responden yaitu 0,72 dan tertinggi nilainya adalah 0,97 dengan rata-rata nilai 0,85 . batas ratarata WHR mahasiswa obes lebih tinggi dibandingkan mahasiswa tidak obes. Angka rata-rata belum dapat dikategorikan beresiko atau tidak beresiko karena responden yang beragam karakteristik terutama jenis kelamin dimana laki-laki yaitu 30 responden dan perempuan yaitu 29 responden. ${ }^{10}$

Hs-CRP merupakan petanda biokimia untuk peradangan dan memprediksikan kelainan koroner (MCI). ${ }^{12}$ Uji yang sangat sensitif untuk mendeteksi resiko penyakit kardiovaskular dan vaskular perifer. Uji ini sering dilakukan bersamaan dengan skrining kolesterol. Sekitar sepertiga penduduk yang mengalami serangan jantung, memiliki kadar kolesterol dan tekanan darah yang normal. Hs CRP yang positif menunjukan bahwa klien beresiko tinggi mengalami penyakit arteri koroner (coronary artery disease, CAD ). Uji ini dapat mendeteksi proses inflamasi, yang terjadi akibat pembentukan plak (aterosklerosis) dalam sistem pembuluh arteri, terutama arteri koroner. Nilai hs-CRP positif jauh lebih rendah daripada nilai standar CRP serum sehingga uji ini menjadi lebih berguna memprediksi penyakit jantung koroner. $^{13}$

Hasil yang didapat, nilai hs-CRP terendah yaitu $0,1 \mathrm{mg} / \mathrm{L}$ dan tertinggi nilainya adalah $9,5 \mathrm{mg} / \mathrm{L}$ dengan rata-rata nilai $1,32 \mathrm{mg} / \mathrm{L}$. Pada kelompok responden tidak obes nilai hs-CRP terendah yaitu 0,1 dan tertinggi nilainya adalah 2,6 dengan rata-rata nilai 0,62 . Sedangkan pada kelompok responden obes nilai hs-CRP terendah yaitu 0,2 dan tertinggi nilainya adalah 9,5 dengan rata-rata nilai 2,01. Angka rata-rata hs-CRP mengindikasikan bahwa rata-rata responden masuk dalam kelompok beresiko rata-rata. Berdasarkan kelompok responden mengindikasikan bahwa pada kelompok tidak obes rata-rata responden masuk dalam kelompok beresiko rendah, sedangkan pada kelompok obes rata-rata responden masuk dalam kelompok beresiko rata-rata. ${ }^{14}$

Hasil penelitian WHR dengan kadar hsCRP serum pada responden didapat hasil uji beda yakni nilai Z untuk WHR yaitu -3,552 dan nilai $Z$ untuk hsCRP yaitu $-4,025$, dengan masing-masing $p=0,000$ yang artinya terdapat perbedaan yang signifikan antara WHR dan kadar hsCRP serum pada kedua kelompok yaitu $\mathrm{p}>0,05$. Berdasarkan kelompok respon-den didapat nilai Mean Rank untuk kadar hsCRP serum pada kelompok tidak obes yaitu 21,95 dan pada kelompok obes yaitu 37,78. Sedangkan nilai Mean Rank untuk nilai WHR pada kelompok tidak obes yaitu 20,86 dan pada kelompok obes yaitu 38,83. Berarti nilai WHR dan kadar hsCRP serum pada kelompok responden obes lebih tinggi daripada kelompok responden tidak obes. Dari hasil penelitian ini juga, didapatkan juganilai WHR dengan kadar hs CRP serum pada responden ditemukan hasil uji korelasi yaitu $\mathrm{p}=0,017$ yang artinya terdapat hubungan yang positif dan signifikan antara nilai WHR dengan kadar hs CRP serum denganp $>0,05$.

Selaras dengan penelitian dari Kim K et al (2008), yang diadakan pada orang Korea, yang menunjukan hubungan yang sangat signifikan antara obesitas sentral dengan total lemak perut yang tinggi dengan hs-CRP. ${ }^{15}$ Juga memperkuat hasil penelitian Emanuela Lapice, dkk (2009) dimana terdapat hubungan yang signifikan antara jumlah lemak perut dengan hs-CRP 
sebagai prediktor resiko penyakit kardiovaskuler. ${ }^{16}$ Peningkatan depot lemak viseral dan adiposit hipertrofi telah dikaitkan dengan tingkat yang lebih tinggi dari peradangan adiposa, sampai saat ini jalur yang tepat menuju ke keadaan proinflamasi dari jaringan adiposa pada individu obesitas tetap teridentifikasi. ${ }^{11}$ Hubungan antara obesitas dan peradangan telah lebih digambarkan oleh peningkatan kadar plasma beberapa penanda proinflamasi termasuk sitokin dan protein fase akut seperti C-reactive protein (CRP) pada orang gemuk. ${ }^{11} \mathrm{CRP}$ dianggap sebagai biomarker independen untuk pengembangan CVD yang menekankan hubungan antara peradangan, obesitas, dan CVD.Independen hubungannya dengan sindrom metabolik, obesitas itu sendiri merupakan faktor risiko yang diketahui untuk perkembangan terjadinya aterosklerosis dan CVD. ${ }^{11}$

Hasil ini berbeda dengan hasil penelitian Veerendra Kumar dan Routhu Warangel (2011) dimana WHR dengan hsCRP memiliki hubungan tapi tidak terlalu signifikan dibandingkan penilaian BMI dengan hs-CRP. WHR hanya berpengaruh signifikan pada responden laki-laki dibandingkan wanita. $^{17}$ Hal ini diakibatkan karena distribusi lemak laki-laki lebih banyak dibagian pinggang sedangkan perempuan lebih banyak dibagian bokong. Penyebabnya adalah pengaruh efek hormonal selama pubertas. Estrogen yang tinggi pada perempuan mendorong deposisi lemak sekitar bokong lebih banyak (gynoid fat distribution), sedangkan testosterone yang tinggi menyebabkan deposisi lemak sekitar pinggang (android fat distribution). ${ }^{9}$

Hasil penelitian Olusegun Mojiminiyi, Fahd Mulla dan Nabila Abdella (2009) di Kuwait juga menunjukkan WHR hanya memiliki hubungan yang lemah tapi tidak signifikan dengan hs-CRP. Waist to hip ratio juga tidak terlalu efektif untuk mendeteksi penyakit kardiovaskular dibandingkan BMI. ${ }^{18}$

Pada penelitian ini didapat arah hubungan positif dan bermakna jadi apabila terjadi peningkatan nilai WHR maka akan terjadi juga peningkatan nilai hs-CRP.
Sebaliknya apabila nilai WHR mengalami penurunan maka nilai hs-CRP juga akan mengalami penurunan.

\section{SIMPULAN}

Berdasarkan hasil penelitian, maka dapat disimpulkan bahwa nilai WHR ratarata pada mahasiswa obes di Fakultas Kedokteran Universitas Sam Ratulangi Manado sebesar 0,85 \pm 0,06. Dan responden dengan WHR tidak beresiko yaitu sebanyak 18 responden (60\%) dan dengan WHR beresiko yaitu sebanyak 12 responden $(40 \%)$. Nilai WHR rata-rata pada mahasiswa tidak obes di Fakultas Kedokteran Universitas Sam Ratulangi Manado sebesar 0,77 \pm 0,04. Dan responden dengan WHR tidak beresiko yaitu sebanyak 28 responden (96,6\%) dan dengan WHR beresiko yaitu sebanyak 1 responden (3,4\%). Nilai hs-CRP serum rata-rata pada mahasiwa obes di Fakultas Kedokteran Universitas Sam Ratulangi Manado sebesar 2,01 $\pm 2,36$. Nilai hs-CRP serum rata-rata pada mahasiwa tidak obes di Fakultas Kedokteran Universitas Sam Ratulangi Manado sebesar 0,62 \pm 0,70. Terdapat perbedaan yang bermakna WHR pada mahasiswa obes dan tidak obes di Fakultas Kedokteran Universitas Sam Ratulangi Manado. Terdapat perbedaan yang bermakna kadar hs-CRP serum pada mahasiswa obes dan tidak obes di Fakultas Kedokteran Universitas Sam Ratulangi Manado.Terdapathubungan yang positif sangat lemah dan bermakna antara WHR dengan kadar hs-CRP serum pada mahasiwa obes dan tidak obes di Fakultas Kedokteran Universitas Sam Ratulangi Manado.

Akhirnya dapat disarankan kepada mahasiswa-mahasiswi untuk mencegah penumpukan lemak berlebihan terutama di bagian perut yang akan mengakibatkan obesitas sentral sehingga terjadi peningkatan nilai hs-CRP, perlu disarankan untuk tetap menjaga nilai waist to hip ratio (WHR) pada batas normal, dan perlu penelitian lebih lanjut tentang hubungan nilai hs-CRP dengan nilai pembanding lainnya juga hubungan nilai WHR dengan 
nilai pembanding lainnya

\section{UCAPAN TERIMA KASIH}

Ucapan terima kasih ditujukan pada Dr. dr. Nelly Mayulu, M.Si, Prof. dr. Nova H Kapantow, DAN, M.Sc, Sp.GK, dan kepada semua pihak yang baik secara langsung maupun tidak langsung telah menumbuhkan ide atau gagasan pada penulis sehingga penulis dapat menyelesaikan artikel ini.

\section{DAFTAR PUSTAKA}

1. Dwipayana M P, Suastika K, Saraswati IMR, Gotera W, Budhiarta AAG, Sutanegara, dkk. Prevalensi Sindroma Metabolik pada Populasi Penduduk Bali, Indonesia. Bali: Bagian/SMF Ilmu Penyakit Dalam FK Unud/RSUP Sanglah Denpasar Bali; 2011.

2. Adriani M, Wijatmadi B. Pengantar Gizi Masyarakat. Jakarta: Kencana Prenada Media Group, 2012.

3. Sihombing M. Hubungan Perilaku Merokok, Konsumsi Makanan/Minuman, dan Aktivitas Fisik dengan Penyakit Hipertensi pada Responden Obes Usia Dewasa di Indonesia. Pusat Penelitian dan Pengembangan Biomedis dan Farmasi. 2010.

4. Riset Kesehatan Dasar. Laporan Nasional 2007.Badan Penelitian dan Pengembangan Kesehatan Departemen Kesehatan, Republik Indonesia. 2008. Hal ix.

5. Shintawati R. Waist to hip ratio sebagai determinan dari takikardi hipertensi pada wanita obese. Bandung: Jurusan pendidikan biologi, FPMIPA Universitas Pendidikan Indonesia. 2008.

6. Feitosa M, Borecki I, Hunt S, Arnett D, Rao D C, Province M. Inheritance of the waist-to-hip ratio in the national heart, lung, and blood institute family heart study. Missouri. 1999.

7. Hariadi, Ali AR. Hubungan obesitas dengan beberapa faktor resiko penyakit jantung koroner di laboratorium klinik prodia makassar tahun 2005. Makassar. 2005.

8. Susanto HK, Adam J. Plasminogen activator inhibitor-1 and high sensitivity c- reactive protein in obesity. Makassar: The Indonesian Journal of Medical Science. 2009. Vol. 2. Hal 24.

9. Sutanto DS. Akupuntur untuk obesitas (kegemukan) melalui pendekatan neuroendokrin. 2008 : Meridian. Vol XV. No 2.

10. WHO. Circumference and Waist-Hip Ratio Report of a WHO Expert Consultation. Geneva. 2008 Availableat: http://whqlibdoc.who.int/publications/201 1/9789241501491_eng.pdf

11. Stienstra R, Duval C, Muller M, Kersten S. PPARs, Obesity, and Inflammation. USA: National Center for Biotechnology Information, U.S. National Library of Medicine. 2007.

12. Kosasih EN, Kosasih AS. Tafsiran hasil pemeriksaan laboratorium klinik. Tangerang: Karisma Publishing Group. 2008. Hal 211.

13. Kee JL. Pedoman pemeriksaan laboratorium \& diagnostik. Jakarta: Penerbit buku kedokteran Ed 6. 2008. Hal 146.

14. Laboratorium klinik prodia. Available at: www.prodia.co.id

15. Kim K, Valentine RJ, Shin Y, Gong K. Associations of visceral adiposity and exercise participation with C-reactive protein, insulin resistance, and endothelial dysfunction in Korean healthy adults. South Korea: Metabolism - Clinical and Experimental.2008. Vol 57. p 1181-9.

16. Lapice E, Maione S,Patti L, Cipriano $P$, Rivellese A,Riccardi G, et al. Abdominal Adiposity is Associated With Elevated CReactive Protein Independent of BMI in Healthy Tidak obese People. USA: American Diabetes Association. 2009.

17. Arumalla VK, Kathyaini R. Serum high sensitivity C- reactive protein in different grades of obesity. India: Research Journal of Pharmaceutical, Biological and Chemical Sciences. 2011. Vol 2. P 1041.

18. Mojiminiyi OA, Mulla FA, Abdella N. Which Obesity Index Best Explains the Link between Adipokines, Coronary Heart Disease Risk and Metabolic Abnormalities in Type 2 Diabetes Mellitus?. Kuwait: Medical Principles and Practice, International Journal of the Kuwait University Health Sciences Centre. 2009. Vol 18. No 2. 